\title{
Development of a quantitative PCR method to differentiate between viable and nonviable bacteria in environmental water samples
}

\author{
Phillip B. Gedalanga $\cdot$ Betty H. Olson
}

Received: 26 September 2008 / Revised: 17 December 2008/Accepted: 26 December 2008 / Published online: 20 January 2009

(C) The Author(s) 2009. This article is published with open access at Springerlink.com

\begin{abstract}
Ethidium monoazide bromide (EMA) treatment of pure culture and environmental waters at low concentrations $(1.0-7.5 \mu \mathrm{g} / \mathrm{ml})$ indicated effective enumeration of viable and viable but nonculturable Escherichia coli in pure cultures, creek waters, and secondary activated sludge effluent samples by quantitative polymerase chain reaction (qPCR) amplification of the $u i d \mathrm{~A}$ and $f l i \mathrm{C}$ gene targets at turbidity values $<10$ NTU. However, EMA treatment was not effective in primary clarifier and secondary trickling filter effluents where turbidities were $\geq 10$ NTU. In viable pure cultures, rapidly dividing and senescent cells were most affected by increasing EMA concentrations. Amplification of heat-killed pure bacterial cultures decreased 4 to 6 logs depending on EMA concentration and culture age. The greatest difference was observed in 5-h cultures using $7.5 \mu \mathrm{g} / \mathrm{ml}$ EMA. Turbidity $(\geq 100 \mathrm{NTU})$ in environmental samples inhibited EMA effectiveness on viability discrimination. Enumeration of $E$. coli in certain wastewaters using EMA-qPCR was similar to culture suggesting that EMA treatment could be incorporated into qPCR assays for the quantification of viable bacteria increasing assay time no more than $30 \mathrm{~min}$. Our results indicate that EMA can be
\end{abstract}

P. B. Gedalanga

Department of Environmental Health, Science, and Policy,

University of California,

Irvine, 1368 Social Ecology II,

Irvine, CA 92697, USA

B. H. Olson $(\bowtie)$

Department of Civil and Environmental Engineering,

University of California,

Irvine, 1368 Social Ecology II,

Irvine, CA 92697, USA

e-mail: bholson@uci.edu used in routine qPCR assays, but optimum conditions for exposure must be identified for each sample type due to sample matrix effects such as turbidity.

Keywords Cell viability Escherichia coli . qPCR · Ethidium monoazide bromide .

Environmental and wastewaters

\section{Introduction}

Recent advances in molecular techniques have improved pathogen detection sensitivity and specificity as well as reduced the time to result. Yet, considering these technological advances, molecular-based methods lack a simplistic and rapid measure of cell viability. Issues related to cell viability and/or infectivity continue to prevent adoption of polymerase chain reaction (PCR) and quantitative polymerase chain reaction (qPCR) methodologies by public health, water, and wastewater agencies for compliance and routine monitoring. The problem stems from the relatively long persistence of DNA after cell death (Dupray et al. 1997; Josephson et al. 1993; Masters et al. 1994) as well as inhibition and interference due to environmental matrices.

While avenues exist in which qPCR can be modified to determine cell viability in environmental samples through techniques such as reverse transcriptase PCR (RT-PCR or RT-qPCR), these methods can be difficult to implement due to the instability of RNA, problems associated with extracting RNA directly from environmental matrices, and variation caused by the physiological condition of the cell. (Condon and Squires 1995; Norton and Batt 1999; Sheridan et al. 1998). Ethidium monoazide bromide (EMA) treatment prior to DNA extraction is a simple approach to viable quantification that relies on preventing PCR amplification 
of genetic targets from nonviable cells (Lee and Levin 2006; Nocker and Camper 2006; Nogva et al. 2003; Rudi et al. 2005a; Wang and Levin 2005). EMA is a phenanthridinium DNA/RNA intercalating dye that enters cells with damaged membranes and covalently binds to DNA upon photoactivation inhibiting downstream molecular applications such as PCR. However, caveats, as described by Nocker and Camper (2006), include the reduced recovery of total genomic DNA caused by EMA treatment regardless of cell viability and the tendency of this compound to permeate the membranes of viable organisms at high concentrations. This suggests further optimization is required before EMA treatment can be incorporated into a viability assay prior to nucleic acid extraction of environmental samples. Additionally, investigators have noted negative impacts of high EMA concentrations on qPCR; thus, it is important to ascertain if the amplification of injured or senescent cells would be inhibited when EMA is incorporated into the experimental design because these cells may be the most susceptible to treatment and could lead to false-negative results.

The goal of this research is to determine the limits of EMA treatment for the differentiation of viable and nonviable bacteria in a qPCR protocol for wastewater treatment samples. For this purpose, we designed experiments to delineate the limitations of such a viability assay using EMA in qPCR as related to culture age, concentration of EMA, and turbidity effects from environmental matrices. We selected traits associated with Escherichia coli because a number of environmental waters and various stages of sewage treatment contain this organism in a broad range of concentrations, and they are believed to be present in active, viable but nonculturable (VBNC) and nonviable physiological states. Further, E. coli is considered an important microbial source-tracking organism used to differentiate fecal pollution sources and as a water quality standard in recreational waters. A molecular-based viability assay using EMA would provide a method that can be used to improve wastewater management practices by optimizing important microbiological populations as well as benefiting water quality officials through rapid and accurate monitoring of potential pathogenic bacterial indicators in the environment, especially those in recreational settings.

\section{Material and methods}

Bacterial strains E. coli O157:H7 (ATCC 43895) was used in all pure culture experiments. Cultures were inoculated into $10 \mathrm{ml}$ of Luria-Bertani (LB) broth, grown on an orbital shaker (Beckman) at $150 \mathrm{rpm}$ for 5,18 , and 40 at $37^{\circ} \mathrm{C}$. $\mathrm{CFU} / \mathrm{ml}$ were enumerated on both LB agar and mTEC media by membrane filtration. LB agar plates were incubated at $37^{\circ} \mathrm{C}$ overnight, and mTEC plates were incubated at $35.5^{\circ} \mathrm{C}$ for $2 \mathrm{~h}$ followed by incubation at $44.5^{\circ} \mathrm{C}$ overnight. Pure cultures were adjusted at $600 \mathrm{~nm}$ to an optical density of 0.25 by dilution with LB medium (Difco) to equalize cell density for all ages tested. For longterm storage, cultures were kept in a $50 \%$ solution of glycerol and LB broth and stored at $-80^{\circ} \mathrm{C}$.

Environmental samples and stress conditions Primary effluent, secondary activated effluent, secondary trickling filter effluent, anaerobic digester sludge, and creek waters were collected in sterile $250 \mathrm{ml}$ bottles. Samples were transported on ice and processed upon arrival. For the nonviable experiments, environmental samples and pure cultures of $E$. coli $\mathrm{O} 157: \mathrm{H} 7$ were heated to $100^{\circ} \mathrm{C}$ for $10 \mathrm{~min}$. Viability loss was confirmed by plating $100 \mu \mathrm{l}$ on mTEC media in triplicate. Plated samples were incubated at $35.5^{\circ} \mathrm{C}$ for $2 \mathrm{~h}$ then transferred to $44.5^{\circ} \mathrm{C}$ for $18-22 \mathrm{~h}$.

EMA treatment EMA (phenanthridium, 3-amino-8-azido-5ethyl-6-phenyl bromide; Biotium, Hayward, CA, USA) was dissolved in water to a stock concentration of $1 \mathrm{mg} / \mathrm{ml}$ and stored in the dark at $-50^{\circ} \mathrm{C}$. Samples were treated as described by Rudi et al. (2005a) with slight modifications. Briefly, $1 \mathrm{ml}$ of sample was centrifuged at $13,000 \times \mathrm{g}$ for $10 \mathrm{~min}$, the supernatant removed and the pellet resuspended in $1 \mathrm{ml}$ of EMA at concentrations of $0,1,2,3,5$, and/or $7.5 \mu \mathrm{g} / \mathrm{ml}$ followed by incubation in the dark at room temperature for $5 \mathrm{~min}$. A $150-\mathrm{W}(12 \mathrm{~V})$ incandescent bulb was used to photoactivate EMA to extracellular DNA at a distance of $20 \mathrm{~cm}$ for $0,1,3,5$, and $10 \mathrm{~min}$ for crosslinking optimization. The solution was centrifuged for $5 \mathrm{~min}$ at $10,000 \times g$, washed in sterile $\mathrm{HPLC} \mathrm{H}_{2} \mathrm{O}$, and centrifuged again to remove trace amounts of EMA solution. Each EMA-treated pellet was then subjected to DNA extraction.

EMA concentration optimization The concentration of EMA was optimized in both environmental samples and pure cultures of E. coli O157:H7. All culture ages and sample types were processed with the concentrations described in the treatment protocol outlined above. After treatment, samples were quantified using qPCR for the $f l i \mathrm{C}$ and uidA genes in pure cultures and environmental samples, respectively, as well as standard culture techniques using mTEC media.

EMA cross-linking optimization time To determine optimal photoactivation times, viable and nonviable $E$. coli $\mathrm{O} 157$ : $\mathrm{H} 7$ cultures were treated with $7.5 \mu \mathrm{g} / \mathrm{ml}$ of EMA using the exposure times described above. After treatment, samples were quantified using $\mathrm{qPCR}$ for the $f l i \mathrm{C}$ gene and standard culture techniques using mTEC media. 
DNA isolation and quantitation DNA was extracted from pure cultures by boiling cells for $10 \mathrm{~min}$, centrifuging at $10,000 \times g$ for $5 \mathrm{~min}$, and the supernatant was transferred to a new tube after which samples were stored at $-40^{\circ} \mathrm{C}$. Environmental samples were subjected to a modified bead beating with a phenol/chloroform/isoamyl alcohol (25:24:1) extraction method (Yu and Mohn 1999). In 2 ml screw cap tubes, $1 \mathrm{ml}$ of environmental sample was pelleted by centrifugation at $13,000 \times \mathrm{g}$ for $5 \mathrm{~min}$. The pellet was mixed with $1.5 \mathrm{~g}$ of zirconia/silica beads $(0.1 \mathrm{~mm}$ in diameter $)$ and $1 \mathrm{ml}$ DNA extraction buffer $(50 \mathrm{mM}$ Tris- $\mathrm{HCl} \mathrm{pH} 8.0$, $5 \mathrm{mM}$ EDTA, and 3\% sodium dodecyl sulfate) and bead beat for $10 \mathrm{~min}$ using a Vortex Genie adapter (Mo Bio, Carlsbad, CA, USA). The supernatant was transferred to a new 2-ml tube, and the previous step was repeated on the pellet to increase the yield. Ammonium acetate was added to the supernatant at a final concentration of $2 \mathrm{M}$ and incubated on ice for $10 \mathrm{~min}$. The tubes were centrifuged at $13,000 \times g$ for $5 \mathrm{~min}$, and the supernatant was collected into a new tube. Five hundred microliters of phenol/chloroform/ isoamyl alcohol $(25: 24: 1)$ solution was added to the tube, vortexed, and centrifuged at $13,000 \times g$ for $5 \mathrm{~min}$. The aqueous layer was transferred to a new tube, mixed with $500 \mu \mathrm{l}$ of chloroform, and centrifuged at $13,000 \times \mathrm{g}$ for $5 \mathrm{~min}$. The aqueous layer was transferred to a new tube, and the DNA was precipitated using 1 volume of isopropanol and incubated at $-20^{\circ} \mathrm{C}$ for at least $1 \mathrm{~h}$. After incubation, the samples were centrifuged at $13,000 \times g$, and the pellet was rinsed with $70 \%$ ethanol, centrifuged, and allowed to dry. The DNA pellet was resuspended in a final volume of $100 \mu \mathrm{l}$ sterile HPLC $\mathrm{H}_{2} \mathrm{O}$. All DNA extracts were analyzed on a Beckman DU7400 Spectrophotometer (Fullerton, CA) for both DNA concentration and purity.

Quantitative PCR The primer and probe sets used in this study are listed in Table 1. All qPCR reactions were performed in a total volume of $25 \mu$ l solution containing: $5 \mu$ template, $3.5 \mathrm{mM} \mathrm{MgCl}_{2}, 1 \times$ PCR buffer, $200 \mathrm{nM}$ dNTP, 1.0 U AmpliTaq DNA polymerase (Applied Biosystems), $100 \mathrm{nM}$ dual-labeled probe (Biosearch Technologies, Novato, CA, USA), $150 \mathrm{nM}$ forward primer, and
$150 \mathrm{nM}$ reverse primer (Sigma-Genosys, The Woodlands, TX, USA). The respective concentrations for the primers and probes were the same for both the uidA and fliC gene targets. Cycling parameters for $\mathrm{qPCR}$ included an initial denaturation at $94^{\circ} \mathrm{C}$ for $2 \mathrm{~min}$, followed by 40 cycles of $94^{\circ} \mathrm{C}$ for $20 \mathrm{~s}$ and $60^{\circ} \mathrm{C}$ for $45 \mathrm{~s}$. All reactions were performed and analyzed on the Rotorgene 3000 (Corbett Research, Melbourne, Australia). Standard curves for pure culture assays were generated using serial dilutions of total genomic DNA from a pure culture of E. coli $\mathrm{O} 157: \mathrm{H7}$ ranging from $5.0 \times 10^{0}$ to $5.0 \times 10^{4}$ and $5.0 \times 10^{3}$ to $5.0 \times 10^{7}$ copies per reaction for fli $\mathrm{C}$ and $u i d \mathrm{~A}$, respectively. The minimum detection limits are $5.0 \times 10^{0}$ copies per reaction for the fliC gene and $5.0 \times 10^{3}$ copies per reaction for the uidA gene. Quantification of environmental samples was performed with a standard curve derived from spiking genomic DNA, using the above concentrations, into DNA extracts of environmental waters that were negative for the two target traits.

Turbidity effect on EMA treatment Primary clarifier effluent samples were obtained from SMWD. The turbidity of each sample was analyzed on a Hach $2100 \mathrm{~N}$ Turbidimeter (Hach, Loveland, CO, USA). Samples were diluted to 100 NTU for the high turbidity experiments, and a subset of these samples was diluted 1:10 with $\mathrm{ddH}_{2} \mathrm{O}$ to run the low turbidity analysis. Additionally, a heat-killed set of both high and low turbidity samples were prepared to compare the effectiveness of EMA treatment on dead cells under these conditions. Turbidity samples were treated with 0,1 , 5, 7.5, $50 \mu \mathrm{g} / \mathrm{ml}$ EMA and analyzed using qPCR for the uidA gene of E. coli as described above.

Statistical analyses and data normalization The regression functions indicated in each figure and graph were verified using a portion of the experimental data. All $p$ values were determined using a two-tailed Student's $t$ test for the comparison of sample means. Quantitative PCR copies were normalized to the amount of DNA added to each qPCR reaction when required. Error bars in each figure represents $1 \mathrm{SD}$ from the mean.

Table 1 Nucleotide sequence of primers and dual-labeled probes

\begin{tabular}{|c|c|c|c|c|}
\hline Primer or probe & Sequence $\left(5^{\prime} \rightarrow 3^{\prime}\right)$ & $\begin{array}{l}\text { Genbank accession } \\
\text { number }\end{array}$ & $\begin{array}{l}\text { Location within } \\
\text { target gene }\end{array}$ & $\begin{array}{l}\text { PCR product } \\
\text { detected (bp) }\end{array}$ \\
\hline uidA forward & CCAATGGTGATGTCAGC & U00096 & $623-639$ & 285 \\
\hline uidA reverse & CACGCAAGTCCGCATCT & & $906-891$ & \\
\hline uidA probe & FAM-TCACAGCCAAAAGCCAGACAGAGT-BHQ1 & & $761-784$ & \\
\hline fliC forward & AATTCCGGTGTACTGAGCAAA & AY249992 & $1,210-1,231$ & 147 \\
\hline fli C reverse & CAGAGCCGTTATCCTTGTTAAC & & $1,354-1,333$ & \\
\hline fliC probe & FAM-ACCGCGGGTGAATCCAGTGATGC-BHQ1 & & $1,243-1,265$ & \\
\hline
\end{tabular}




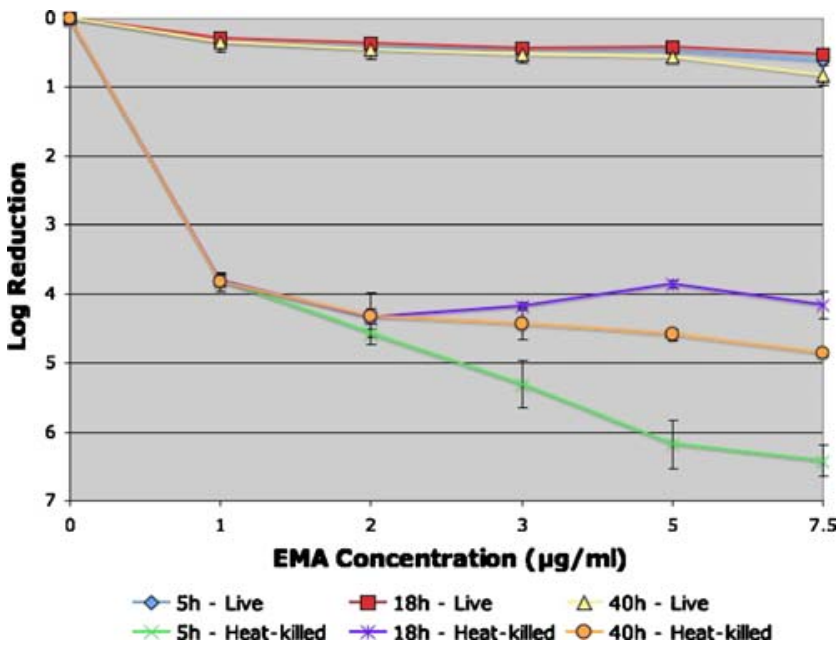

Fig. 1 The relationship between culture age and EMA concentration for live and heat-killed pure cultures of E. coli $\mathrm{O} 157: \mathrm{H} 7$ enumerated using qPCR for the uidA gene

\section{Results}

Effect of EMA treatment on total DNA recovery and the minimum concentration of EMA used to inhibit qPCR amplification of nonviable cells in pure culture

DNA concentrations from 24 separate extractions using pure cultures, three different types of effluents from various treatment plants, and creek water samples were evaluated for potential DNA loss during the EMA treatment and extraction procedures. Mean DNA concentrations for all replicates were not significantly different at any of the concentrations tested up to $7.5 \mu \mathrm{g} / \mathrm{ml}$. In the pure culture experiments, we evaluated the efficacy of low concentrations of EMA to discriminate between viable and nonviable bacteria from cultures at different growth stages (Fig. 1). An inverse relationship between EMA concentration and bacterial quantification was observed in both live and heatkilled cells. In live cultures, the 40-h culture was the most sensitive to EMA treatment followed by the $5 \mathrm{~h}$ culture (Fig. 1). However, there was less than $1 \log$ difference between the treated samples and the controls of live cultures regardless of EMA concentrations up to $7.5 \mu \mathrm{g} / \mathrm{ml}$ and growth stage of the cultures examined.

Treatment of heat-killed cells with $7.5 \mu \mathrm{g} / \mathrm{ml}$ EMA yielded an average qPCR reduction of $5.14 \operatorname{logs}(\mathrm{SD}=1.01)$ for all culture ages tested (Fig. 1). Additionally, the greatest reduction (6.41 \pm 0.23 orders of magnitude) was found in the 5 -h cultures. At $1 \mu \mathrm{g} / \mathrm{ml}$, we were able to observe at least a 3-log reduction from EMA-treated heat-killed cells regardless of culture age. A paired Student's $t$ test showed a statistically significant difference between viable $18 \mathrm{~h}$ cultures and both the 5 -h and the 40-h cultures $(p<0.05)$; however, there was no significant difference between the 5 -h and the 40-h culture ( $p=0.13$ ).

Analysis of variance to determine culture age effects on qPCR of EMA-treated viable $E$. coli cultures

A two-factor analysis of variance (ANOVA) determined that EMA concentration and culture age combined provided a significant influence $(p<0.01)$ on the mean gene copy number as enumerated by qPCR (Fig. 2) for viable cells. Culture age does not have a significant effect when EMA concentration is ignored; however, EMA concentration maintained a significant effect regardless of culture age.
Fig. 2 Analysis of variance (ANOVA) to determine the relationship between culture age and EMA treatment
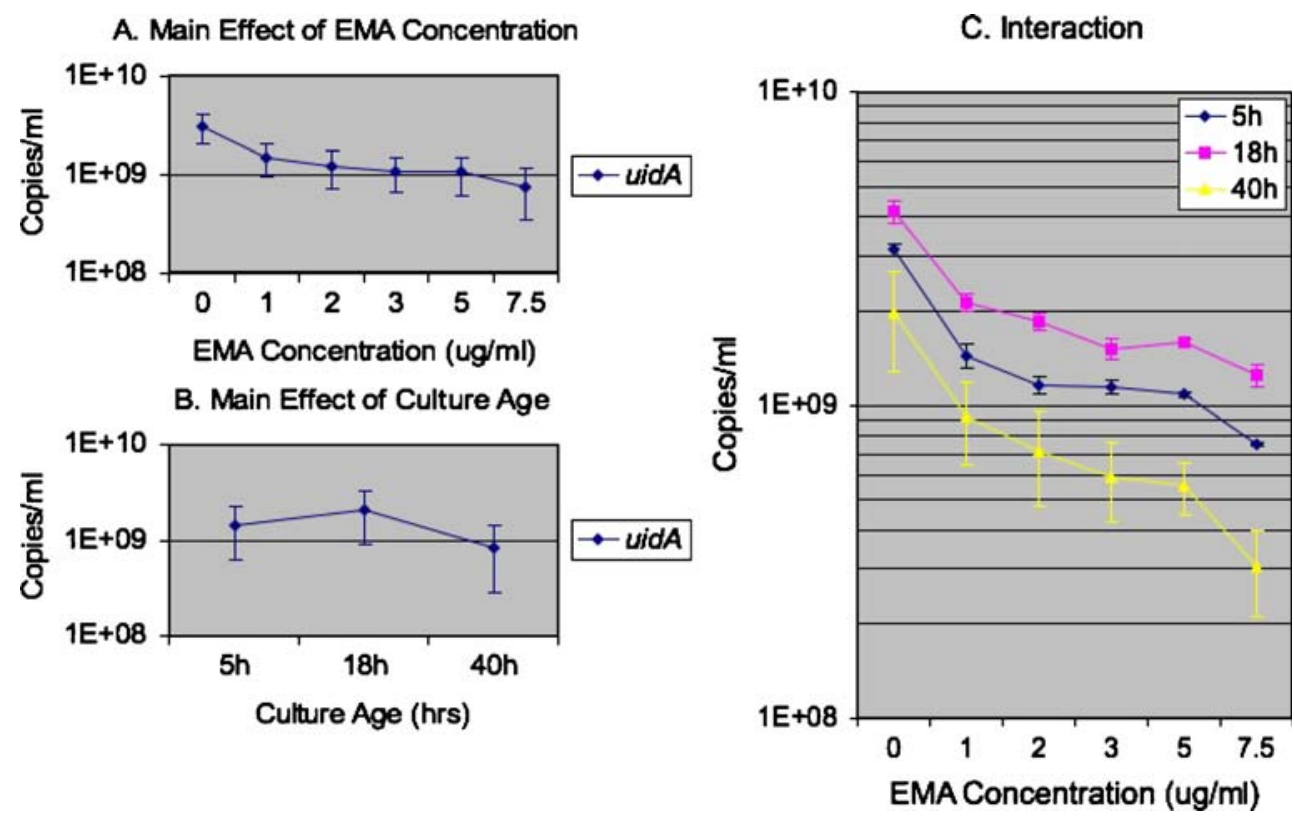
The interaction between these variables indicates that the influence of EMA concentration is more pronounced for different culture ages $(p<0.01)$. More specifically, it appears that EMA inhibition of PCR amplified gene targets is greatest for the 40-h culture followed by the 5-h and the 18 -h culture. However, this analysis does not provide mechanistic evidence for the specific sensitivities among the age groups.

Effect of EMA concentration on the recovery of culturable cells on mTEC media

Pure cultures from different growth phases were treated with EMA and enumerated by qPCR and growth on mTEC media to determine the effect of EMA treatment on cell recovery (Fig. 3). Recovered cells were reduced by at least four orders of magnitude when treated with $7.5 \mu \mathrm{g} / \mathrm{ml}$ EMA; however, there was no significant difference among treated cells and qPCR values. The results indicated no significant differences between the 5-h and 18-h cultures when grown on mTEC media (Fig. 3). However, using a paired Student's $t$ test, the 40 -h culture was significantly different than both the 5-h $(p<0.05)$ and 18-h cultures $(p<0.05)$.

Effect of EMA treatment on qPCR and cell recovery from environmental samples on mTEC media

In order to better understand the problems that can arise in a EMA-qPCR assay using environmental samples, we evaluated the relationship between EMA treatment and cell recovery on mTEC media using both pure cultures and environmental samples, again handled in parallel for treatment and assessment. In wastewater effluent samples, a concentration of $7.5 \mu \mathrm{g} / \mathrm{ml}$ EMA used for treatment did not produce the same extensive reduction in recovered

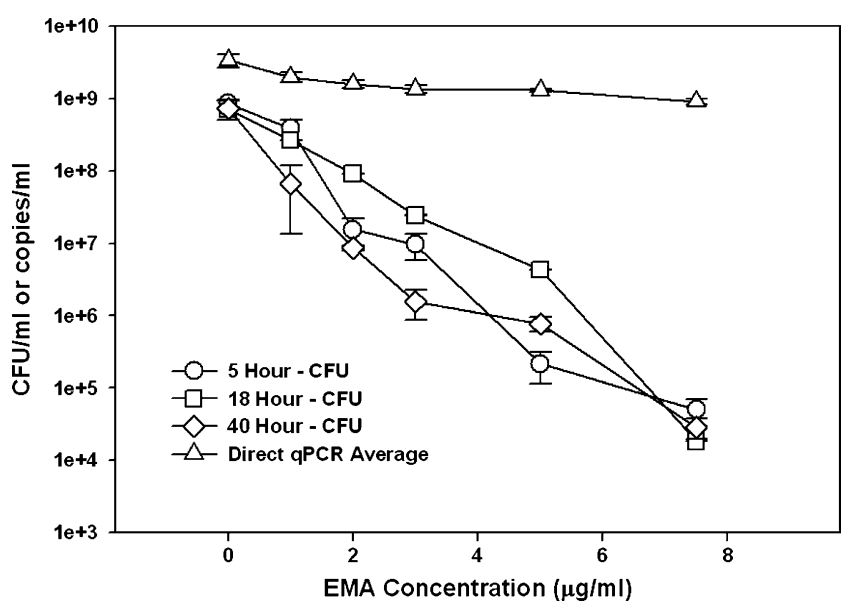

Fig. 3 The relationship between EMA concentration and enumeration of $E$. coli $\mathrm{O} 157: \mathrm{H} 7$ using both $\mathrm{qPCR}$ for the fli $\mathrm{C}$ gene and standard culture techniques on mTEC media

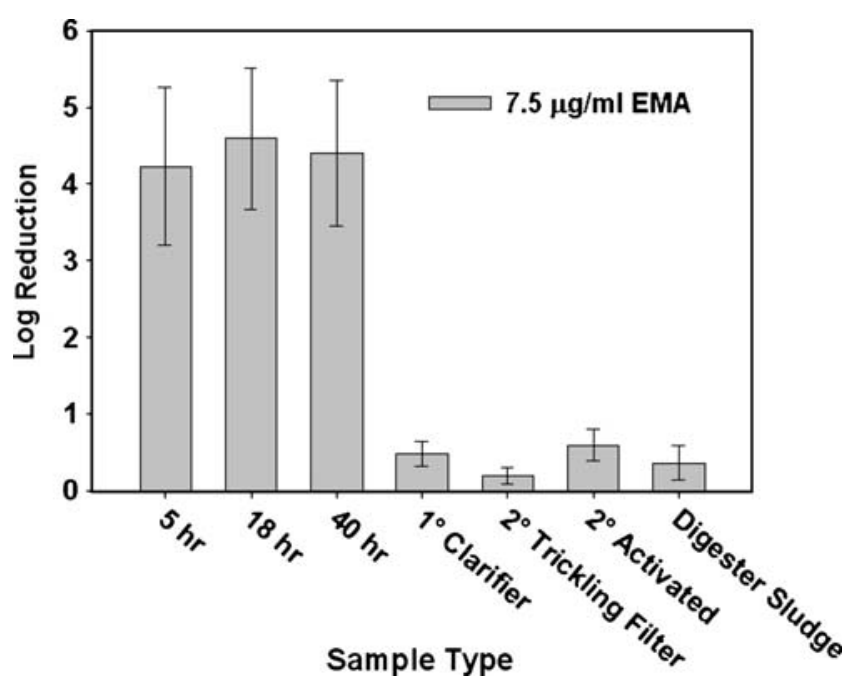

Fig. 4 The log reduction between pure cultures and environmental samples exposed to 0 and $7.5 \mu \mathrm{g} / \mathrm{l}$ EMA for $E$. coli cultured on mTEC media

bacteria on mTEC media that was evident in pure culture experiments (Fig. 4). Pure cultures experienced a reduction of approximately four orders of magnitude for $E$. coli recovered on mTEC media. Secondary activated sludge effluent had the lowest turbidity (1-2 NTU) and produced the largest difference in cell counts from treated and untreated environmental samples at $7.5 \mu \mathrm{g} / \mathrm{ml}$ EMA.

Efficacy of lower EMA concentrations for treatment to discriminate between viable and nonviable cells in environmental samples

The differentiation of viable but nonculturable, nonviable, and culturable cells is clearly shown in Fig. 5, where

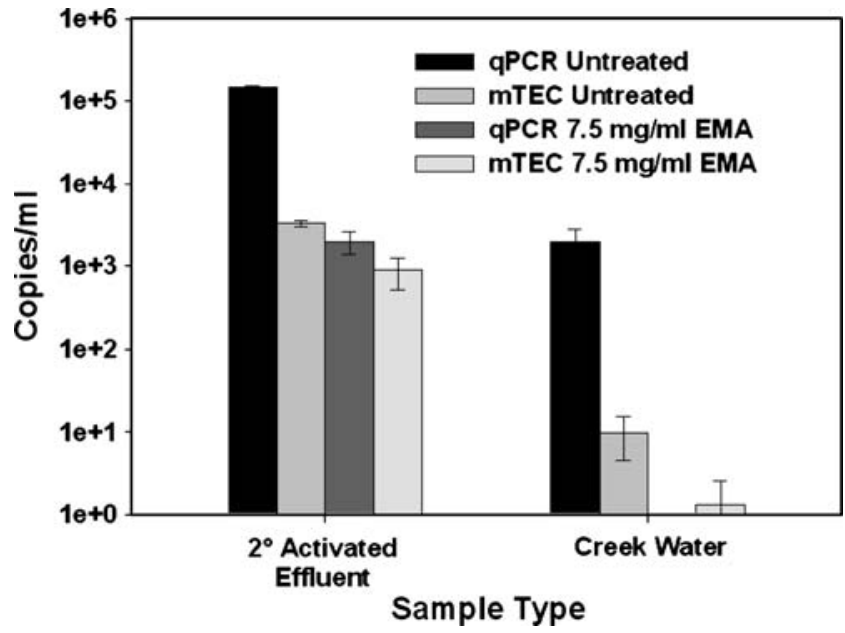

Fig. 5 Analysis of secondary activated effluent and creek waters for viable $E$. coli using $7.5 \mu \mathrm{g} / \mathrm{ml}$ EMA for treatment combined with both qPCR for the uidA gene and standard culture methods on mTEC media 
concentrations of target bacteria from untreated secondary activated sludge effluent and creek water samples determined by qPCR and conventional culture techniques are compared with concentrations of treated samples using the same techniques. EMA-qPCR treated samples are indicative of the viable and viable but nonculturable bacteria population; therefore, the difference between control samples enumerated on mTEC media and EMA-qPCR samples identified the population of viable but nonculturable cells. In secondary effluent, this value was less than $1 \mathrm{log}$ and was below the detection limit $\left(5 \times 10^{3}\right.$ copies $/ \mathrm{ml}$ of sample) in creek water samples (Fig. 5). In both sample types tested, qPCR of the untreated samples significantly $(p<0.05)$ overestimated the number of viable or viable but nonculturable bacteria.

Primary clarifier and secondary trickling filter effluent samples were treated with EMA concentrations ranging from 0 to $50 \mu \mathrm{g} / \mathrm{ml}$ and enumerated using qPCR in the same manner as the pure culture experiments (Fig. 6). In the live primary clarifier effluent samples, we observed a reduction of $1.13(\mathrm{SD}=0.75)$ orders of magnitude between the $0-$ and $50-\mu \mathrm{g} / \mathrm{ml}$ EMA; however, between $1-7.5 \mu \mathrm{g}$ $\mathrm{EMA} / \mathrm{ml}$, no significant differences in $\mathrm{qPCR}$ values were noted. In the live secondary trickling filter effluent samples, the reduction between the $0 \mu \mathrm{g} / \mathrm{ml}$ EMA and the $50 \mu \mathrm{g} / \mathrm{ml}$ EMA samples was $1.51(\mathrm{SD}=0.35)$ orders of magnitude. Comparing EMA treatment at $50 \mu \mathrm{g} / \mathrm{ml}$ of heat-killed cells in primary and secondary effluents, the reduction was 1.21 $\log (\mathrm{SD}=0.96)$ and $2.03 \log (\mathrm{SD}=0.72)$, respectively.

Inhibition of EMA treatment caused by high levels of turbidity

Primary clarifier effluent samples diluted to 10 and 1 NTU were analyzed to determine the effect of turbidity on EMA treatment (Fig. 7). Using $7.5 \mu \mathrm{g} / \mathrm{ml}$ EMA, we were able to see a statistically significant difference for the 1 NTU samples $(p<0.01)$. At this turbidity, live cells were amplified, and the DNA from nonviable cells was inhibited by EMA treatment. Again, the amplification of DNA from nonviable cells occurred when qPCR was not coupled with EMA treatment. At $50 \mu \mathrm{g} / \mathrm{ml}$ EMA, there was a significant difference between 10 and 1 NTU samples. This concentration of EMA resulted in a 5-log reduction of amplified targets from live 1 NTU samples. Additionally, EMA treatment was tested at a turbidity of 100 NTU; however, we did not observe a reduction in amplification of targets from live and heat-killed cells even at a concentration of $50 \mu \mathrm{g} / \mathrm{ml}$ EMA (data not shown).

\section{Discussion}

The importance of bacterial viability continues to play a major role in methods development. EMA treatment as a viability assay for qPCR-based methods has been criticized because at high concentrations it penetrates viable cells resulting in lower qPCR results (Flekna et al. 2007) and reduces total DNA recovery (Nocker and Camper 2006). A follow-up study by Nocker et al. (2006) suggested using propidium monoazide bromide due to its higher affinity for DNA and is less damaging to cell membranes; however, these benefits include increased economic costs. Our approach to these issues was to adopt a lower maximum concentration of EMA as Lee and Levin (2006) and Wang and Levin (2005) had, as well as to evaluate a range of EMA concentrations equal to or less than $7.5 \mu \mathrm{g} / \mathrm{ml}$. We found that EMA treatment at these concentrations resulted in no significant differences in DNA yield between live and dead cells (data not shown), which we attribute to the
Fig. 6 The relationship between EMA concentration and enumeration of live and heat-killed cells from primary clarifier and secondary trickling filter effluent using qPCR for the uidA gene of E. coli

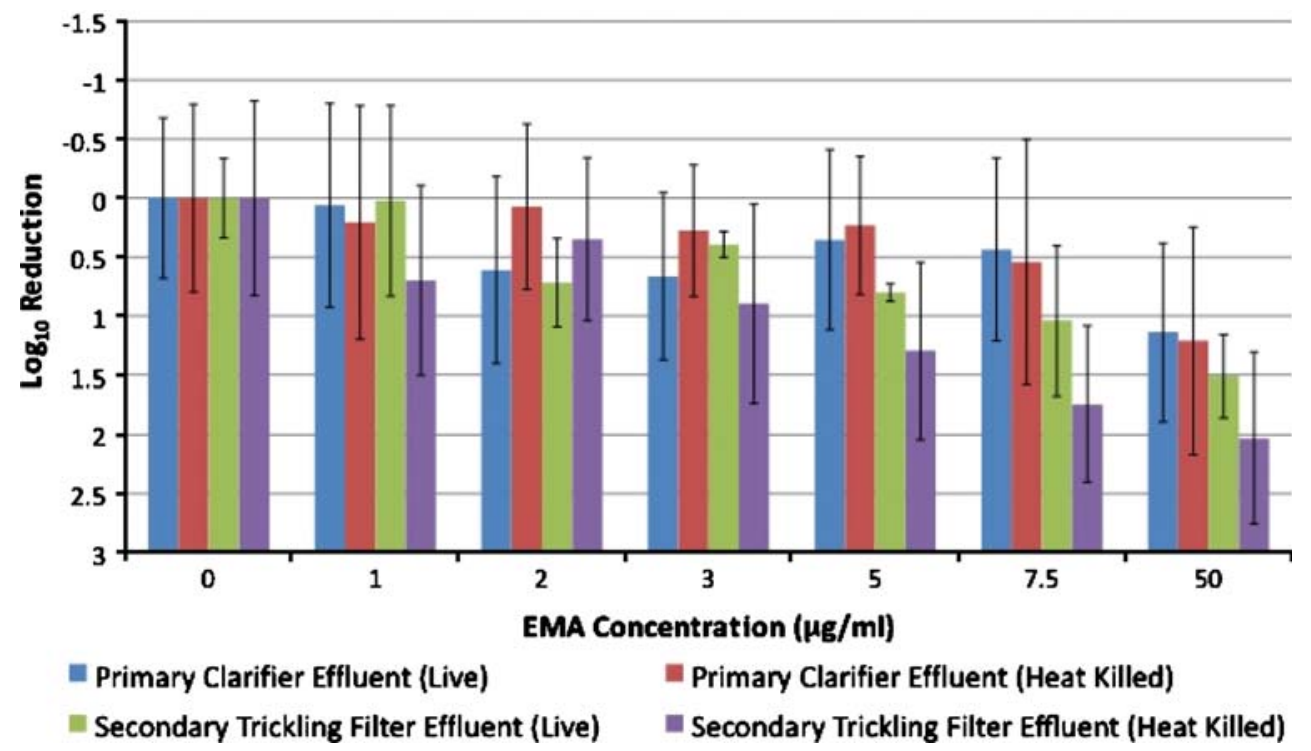


Fig. 7 Evaluating the relationship between turbidity and EMA concentration on the effectiveness of treatment for the enumeration of live and heat-killed $E$. coli in primary clarifier effluent diluted to 1 and 10 NTU

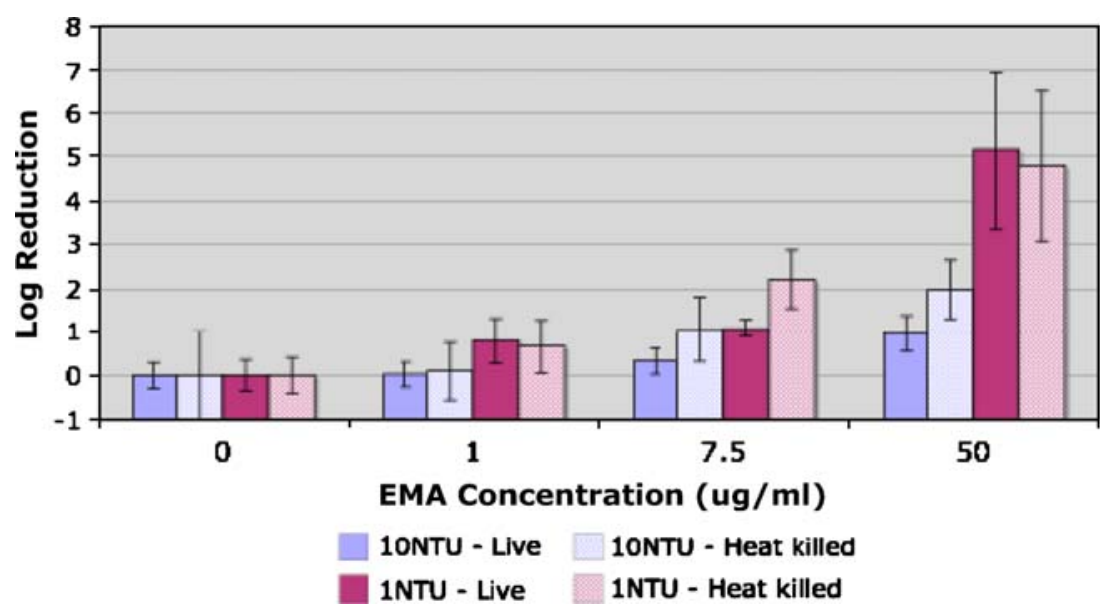

decrease in EMA concentration and to our DNA extraction method. We chose a DNA extraction procedure that was not dependent on purification columns, thus avoiding any DNA loss attributed to changes in the binding affinity of DNA to purification columns due to EMA treatment.

Importantly, EMA treatment to differentiate viable from nonviable cells assumes viability based on cell membrane integrity. For our purposes, we chose to incorporate heat inactivation for both pure cultures and environmental samples. While heat inactivation sufficiently disrupts bacteria cell membranes, the issue of viability may be biased in cases for which the membrane remains intact. This study would benefit from a UV inactivation analysis because UV treatment may produce nonviable bacteria without disrupting the cell membrane. Similarly, chloramine treatment inactivates bacteria, while leaving the outer cell membrane intact (Stewart and Olson 1996), thus bacteria existing in these states may be exceptions to viability differentiation using EMA-qPCR. Additionally, extracellular genetic material is able to permeate the membranes of chemically competent cells; therefore, these bacteria may be sensitive to EMA treatment regardless of concentration.

The effects of EMA treatment on bacteria in different growth phases provide further evidence to incorporate low EMA concentrations in a viability assay (Fig. 2). Our results show that cultures in log phase growth are least affected by EMA treatment compared to those in early log phase or stationary phase growth. Composition of the cell wall undergoes changes as the cell progresses through different growth phases. These changes increased permeability of EMA (Fig. 2), thus influencing assay accuracy. EMA concentrations greater than $7.5 \mu \mathrm{g} / \mathrm{ml}$ for the treatment of pure cultures led to significant reduction of qPCR precision (data not shown). At $7.5 \mu \mathrm{g} / \mathrm{ml}$ EMA, we were able to accurately quantify bacteria treated using qPCR, even though at this concentration we observed a reduction of approximately five orders of magnitude in
CFUs of pure cultures grown on selective media (Fig. 3). In contrast, Flekna et al. (2007) and Nocker and Camper (2006) used environmental samples spiked with cultured cells treated at high EMA concentrations; therefore, they observed significant decreases in qPCR results. Our data showing loss of ability to grow on media at low concentrations agrees with their findings that cells are negatively affected, and the disparity in results may be due to differences in EMA concentration.

The relationship between EMA concentration and culture enumeration on media is important because it raises the question of how EMA treatment inhibits cell growth without intercalating with the DNA, and it demonstrates a negative impact on the cell by inhibiting cell reproduction. Treating with high concentrations of EMA reduced the quantity enumerated by qPCR (Flekna et al 2007) as well as inhibited growth on media. These results, along with our data, suggest that a delicate balance exists between acceptable EMA concentrations; therefore, optimization is necessary. Interestingly, the effect on cellular growth was much less for target organisms that naturally occur in environmental samples treated with the same concentration and grown on selective media, which raises the question of EMA treatment inhibition caused by the environmental matrix. Our study was designed to examine the effectiveness of EMA treatment on low concentrations of in situ $E$. coli populations in environmental waters because such concentrations are important in water quality testing. Flekna et al. (2007) demonstrated that EMA at $5-10 \mu \mathrm{g} / \mathrm{ml}$ produced concentrations of EMA-stained cells that agreed with the number of dead cells within 1 log as determined by a Live/Dead ${ }^{\circledR}$ BacLight ${ }^{\mathrm{TM}}$ test. Hence, disagreement in the accuracy of assessing dead cells appears to be explained by the higher concentrations of EMA $(>10 \mu \mathrm{g} / \mathrm{ml})$ used for treatment of environmental samples in most studies (Nocker and Camper 2006; Rudi et al 2005b; Rudi et al 2005b). Additionally, our data on in situ targets from natural samples reinforced the well-known concept that 
environmental conditions rarely mimic laboratory culture conditions (Figs. 4, 5, 6, and 7). These findings and their variance from the published literature on EMA emphasize the importance of analyzing the effectiveness of EMA treatment directly on environmental samples containing naturally occurring target organisms.

Reasons for the failure of laboratory-grown cultures to mimic how in situ bacteria react to various treatment processes or environmental conditions are well documented (Bernhardt et al. 2003; McGee et al. 2002). Factors such as temperature, conductivity, and flow have been found to negatively influence bacterial populations in water environments (He et al. 2007) suggesting that fecal bacteria found in these waters often survive in suboptimal conditions. Additionally, evidence that membrane characteristics may aid survival of an organism as it progresses through treatment has been published; albeit most publications draw inferences as opposed to showing actual changes in membrane properties or respiration (Mirpuri et al. 1997). Alterations in the cell membrane composition have been shown for cultured bacteria grown under low nutrient conditions (Stewart and Olson 1992), which may produce cells with different susceptibilities to compounds such as EMA that penetrate the cell membrane than bacteria grown under high nutrient conditions. Further, negative impacts of EMA treatment are exacerbated by the suboptimal conditions that exist for target bacteria in the environment (Fig. 5). Our data provided experimental evidence of a change in cell physiology because we observed a 1-log decrease in qPCR results of viable cultures and much greater decrease in CFU, which differed significantly from our findings using secondary activated sludge effluent and creek water samples at 1-2 NTU (Fig. 5).

Competition for nutrients among microorganisms, chemicals used, or treatment conditions present in these environments can result in starved, injured, or dead microorganisms. Under these environmental conditions, it is imperative that EMA treatment be optimized so as not to exclude EMA sensitive bacterial populations from quantitative analysis. EMA treatment at high concentrations reduced qPCR values, and the hypothesized mechanism was penetration of spiked culture cell walls. At lower concentrations, it was clear that $7.5 \mu \mathrm{g} / \mathrm{ml}$ EMA was effective at differentiating live and heat-killed $E$. coli which agrees with the results of a previous study by Guy et al. (2006) who reported that as little as $7.5 \mu \mathrm{g} / \mathrm{ml}$ EMA was sufficient to discriminate between viable and nonviable cells in fecal swabs.

No other study using viability compounds has examined the effect of turbidity on EMA-qPCR; however, it does seem to play a major role in the effectiveness of EMA treatment. We demonstrated that EMA treatment did not adequately differentiate between live and heat-killed cells in primary clarifier and secondary trickling filter effluents (Fig. 6) with high turbidities ( $>10$ NTU). Such samples contain suspended solids, cells embedded in particulates, or cell clumping, which could prevent EMA penetration or interfere with photoactivation of EMA resulting in a decreased effectiveness of treatment as sample turbidity increased (Fig. 7). Since amplification of dead cells continued to be observed in primary and trickling filter secondary effluents, but not heat killed cultured cells, the inefficiency of EMA appears to be due in part to matrix effects during exposure. Decreases in disinfectant efficiency in the presence of particulate turbidity or clumped microorganisms are widely reported in the literature (Cantwell and Hofmann 2008; Lechevallier et al. 1981; Ridgway and Olson 1981) and support our conclusion on matrix effects. Our data showed that the effect of high levels of turbidity could be easily counteracted by diluting samples to $1-2$ NTU (Fig. 7) before treatment.

Data in the literature also support our conclusion that photoactivation of EMA could also be decreased by turbidity levels. Kay et al. (2005) showed that highly turbid samples increased the survival of indicator organisms, both bacteria and viruses, in the presence of sunlight, while Jeng et al. (2005) showed that bacteria associated with sediments had survived far longer than bacteria in the water column. Both of these studies suggest that high turbidity levels would decrease light penetration and consequently, photoactivation of EMA. Based on the data in our study, as well as these other studies, EMA use in natural waters with turbidities greater than 2 NTU could produce variable or inaccurate results due to alterations in photoactivation, decreases in chemical penetration due to adsorption or absorption to particles or penetration of only the outer layer of clumped bacteria. While dilution may be an excellent way to correct turbidity in samples with high concentrations of target bacteria, in samples with low concentrations, falsenegatives results may occur if any proportion of the population is EMA sensitive. It is likely that any chemical that relies upon photoactivation to differentiate live and dead cells including PMA would experience the same problem. Although our investigation did not focus on increasing cell concentration and EMA effectiveness, Nocker and Camper (2006) adjusted cell number to an O.D. $600 \mathrm{~nm}$ of 1 during their investigations, which suggests that high cell concentrations may also result in reductions of chemical dispersion and photoactivation, which is indirectly suggested by high concentrations of EMA that were used.

Molecular-based methods have gained popularity because of their increased sensitivity and reduced time to result, yet many are only being used as a secondary identity confirmation because these methods quantify viable and nonviable targets which can result in overestimations of 
targets in environmental samples. He and Jiang (2005) investigated enterococci in the environment and found that qPCR was more sensitive than plating techniques in sewage samples but produced overestimations when examining chlorinated sewage samples demonstrating that dead cells were amplified. Viability is addressed by several methods, the most popular being, reverse transcriptase PCR (RTPCR) and quantitative reverse transcriptase PCR (qRTPCR) which are the standard for viability discrimination. However, these methods can be difficult to implement for environmental samples, and expression has been shown to vary by gene and also with cell growth phase adding to the complexity of assay development (Condon and Squires 1995; Matsuda et al. 2007; Yaron and Matthews 2002). Further, Yaron and Matthews (2002) have shown that while $f l i \mathrm{C}$ and stx 1 mRNA were degraded by autoclaving, the mRNA of the $r f b \mathrm{E}$ gene remained unaffected which suggests that care must be taken when selecting mRNA targets or inaccurate measurements of cell viability will result. Another study by Sheridan et al. (1998) reported that mRNA became undetectable between 2 and $16 \mathrm{~h}$ for heatkilled cells, while for ethanol-treated cells, the mRNA remained detectable after $16 \mathrm{~h}$. This suggests that using mRNA as an indicator of viability requires very complete knowledge of preservation/kill methods and gene expression. All the above studies emphasize the importance of a simple molecular-based method to accurately quantify viable bacteria. EMA-qPCR methods can accurately and rapidly quantify viable bacteria in wastewater effluents, but when turbidities exceed 2 NTU in environmental wastewater effluent samples, DNA can be amplified from heat killed targets.

An EMA-qPCR methodology does not significantly increase the time to result, as the assay only requires $30 \mathrm{~min}$ and provides the same reliability as conventional culture techniques. These findings can benefit many aspects of water quality by optimizing viable bacterial populations in the microbiological treatment processes of wastewater facilities or improving pathogen monitoring in recreational waters as long as the level of detection of the qPCR assay is well defined and the turbidities monitored. Data gained from molecular monitoring in wastewater facilities when related to certain operational parameters can result in increased microbial efficiency of treatment processes and potential financial savings from energy reductions (Boone 2007). In recreational waters, accurate quantification and monitoring can prevent the unnecessary closure of coastlines and beaches.

Acknowledgements We would like to thank the UC Center for Water Resources grant UCCWR-35554 and the Urban Water Research Center at UC Irvine for funding this study. We thank the Santa Margarita Water District wastewater treatment plant in Orange County for providing wastewater effluent samples. We also thank J.Y. Le, Dr. M.Y. Wang, and W. Chu for their assistance.
Open Access This article is distributed under the terms of the Creative Commons Attribution Noncommercial License which permits any noncommercial use, distribution, and reproduction in any medium, provided the original author(s) and source are credited.

\section{References}

Bernhardt J, Weibezahn J, Scharf C, Hecker M (2003) Bacillus subtilis during feast and famine: visualization of the overall regulation of protein synthesis during glucose starvation by proteome analysis. Genome Res 13(2):224-237

Boone AM (2007) Rapid detection techniques useful for primary indicators of activated sludge treatment optimization. Master's Thesis-Spring 2007. John Hopkins University

Cantwell RE, Hofmann R (2008) Inactivation of indigenous coliform bacteria in unfiltered surface water by ultraviolet light. Water Res 42:2729-2735

Condon C, Squires CL (1995) Control of rRNA transcription in Escherichia coli. Microbiol Rev 59(4):623-645

Dupray E, Caprais MP, Derrien A, Fach P (1997) Salmonella DNA persistence in natural seawaters using PCR analysis. J Appl Microbiol 82(4):507-510

Flekna G, Polonca S, Wagner M, Smulders FJM, Mozina SS, Hein I (2007) Insufficient differentiation of live and dead Campylobacter jejuni and Listeria monocytogenes cells by ethidium monoazide (EMA) compromises EMA/real-time PCR. Res Microbiol 158:405-412

Guy RA, Kapoor A, Holicka J, Shepherd D, Horgen PA (2006) A rapid molecular-based assay for direct quantification of viable bacteria in slaughterhouses. J Food Protection 69(6):1265-1272

He JW, Jiang SC (2005) Quantification of enterococci and human adenoviruses in environmental samples by real-time PCR. Appl Environ Microbiol 71(5):2250-2255

He L, Lu J, Shi W (2007) Variability of fecal indicator bacteria in flowing and ponded waters in southern California: implications for bacterial TMDL development and implementation. Water Res 41:3132-3140

Jeng HC, England AJ, Bradford HB (2005) Indicator organisms associated with stormwater suspended particles and estuarine sediment. J Environ Sci Health 40:779-791

Josephson KL, Gerba CP, Pepper IL (1993) Polymerase chain reaction detection of nonviable bacterial pathogens. Appl Environ Microbiol 59(10):3513-3515

Kay D, Stapleton CM, Wyer MD, McDonald AT, Crowther J, Paul N, Jones K, Francis C, Watkins J, Wilkinson J, Humphrey N, Lin B, Yang L, Falconer RA, Gardner S (2005) Decay of intestinal enterococci concentrations in high-energy estuarine and coastal waters: towards real-time $T_{90}$ values for modeling faecal indicators in recreational waters. Water Res 39:655-667

LeChevallier MW, Evans TM, Seidler RJ (1981) Effect of turbidity on chlorination efficiency and bacterial persistence in drinking water. Appl Environ Microbiol 42(1):159-167

Lee JL, Levin RE (2006) Use of ethidium bromide monoazide for quantification of viable and dead mixed bacterial flora from fish fillets by polymerase chain reaction. J Microbiol Methods 67:456-462

Masters CI, Miles CA, Mackey BM (1994) Effect of stress treatments on the detection of Listeria monocytogenes and enterotoxigenic Escherichia coli by the polymerase chain reaction. J Appl Bacteriol 77(1):73-79

Matsuda K, Tsuji H, Asahara T, Kado Y, Nomoto K (2007) Sensitive quantitative detection of commensal bacteria by rRNA-targeted reverse transcription-PCR. Appl Environ Microbiol 73(1):32-39 
McGee P, Bolton DJ, Sheridan JJ, Earley B, Kelly G, Leonard N (2002) Survival of Escherichia coli O157:H7 in farm water: its role as a vector in the transmission of the organism within herds. J Appl Microbiol 93(4):706-713

Mirpuri RG, Jones WL, McFeters GA, Ridgway HF (1997) Physiological stress in batch cultures of Pseudomonas putida 54G during toluene degradation. J Ind Microbiol Biotechnol 18 (6):406-413

Nocker AN, Camper AK (2006) Selective removal of DNA from dead cells of mixed bacterial communities by use of ethidium monoazide. Appl Environ Microbiol 72(3):1997-2004

Nocker AN, Cheung CY, Camper AK (2006) Comparison of propidium monoazide with ethidium monoazide for differentiation of live vs. dead bacteria by selective removal of DNA from dead cells. J Microbiol Methods 67:310-320

Nogva HK, Dromtorp SM, Nissen H, Rudi K (2003) Ethidium monoazide for DNA-based differentiation of viable and dead bacteria by 5 '-nuclease PCR. BioTechniques 34:804-813

Norton DM, Batt CA (1999) Detection of viable Listeria monocytogenes with a 5' nuclease PCR assay. Appl Environ Microbiol 65(5):2122-2127

Ridgway HF, Olson BH (1981) Chlorine resistance patterns of bacteria from two drinking water distribution systems. Appl Environ Microbiol 44(4):972-987

Rudi K, Moen B, Dromtorp SM, Holck AL (2005a) Use of ethidium monoazide and PCR in combination for quantification of viable and dead cells in complex samples. Appl Environ Microbiol 71 (2):1018-1024

Rudi K, Naterstad K, Dromtorp SM, Holo H (2005b) Detection of viable and dead Listeria monocytogenes on gouda-like cheeses by real-time PCR. Lett Appl Microbiol 40:301-306

Sheridan GEC, Masters CI, Shallcross JA, Mackey BM (1998) Detection of mRNA by reverse transcription-PCR as an indicator of viability in Escherichia coli cells. Appl Environ Microbiol 64 (4):1313-1318

Stewart MH, Olson BH (1992) Physiological studies of chloramine resistance developed by Klebsiella pneumoniae under low nutrient growth conditions. Appl Environ Microbiol 58(9):29182927

Stewart MH, Olson B (1996) Bacterial resistance to potable water disinfectants. In: Hurst CJ (ed) Modeling disease transmission and its prevention by disinfection. Cambridge University Press, pp 140-192

Wang S, Levin RE (2005) Discrimination of viable Vibrio vulnificus cells from dead cells in real-time PCR. J Microbiol Methods 64:1-8

Yaron S, Matthews KR (2002) A reverse transcriptase-polymerase chain reaction assay for detection of viable Escherichia coli O157:H7: investigation of specific target genes. J Appl Microbiol 92:633-640

Yu Z, Mohn WW (1999) Killing two birds with one stone: simultaneous extraction of DNA and RNA from activated sludge biomass. Can J Microbiol 45:269-272 